\title{
Strange case of non-epileptic attacks of speechlessness - A single case study around an understandable misdiagnosis
}

\author{
Erich Kasten $^{1}$, Nadine Sasse ${ }^{2}$ \\ ${ }^{1}$ MSH Medical School Hamburg, University of Applied Sciences and Medical University, Am Kaiserkai 1, D-20457 Hamburg, Germany \\ ${ }^{2}$ Department of Medical Psychology and Medical Sociology, University Medical Center, Georg-August-University, Göttingen, Germany
}

Email addresses:

EriKasten@aol.com (E. Kasten), nadine.sasse76@web.de (N. Sasse)

To cite this article:

Erich Kasten, Nadine Sasse. Strange Case of Non-Epileptic Attacks of Speechlessness - A Single Case Study around an Understandable Misdiagnosis. American Journal of Psychiatry and Neuroscience. Vol. 3, No. 1, 2015, pp. 1-7. doi: 10.11648/j.ajpn.20150301.11

\begin{abstract}
In this single-case study, after a brain-damage, for a young female patient the following diagnoses were supposed in a period of nearly 20 years: depression, posttraumatic stress disorder, dissociative identity disorder, narcissism personality disorder, schizotypic personality disorder with pronounced abnormal behaviour, experiences of insufficiency with problems of segregation, psycho-neurotic symptoms with serious fluctuations of mood, motor inhibition, organic psycho-syndrome after brain contusion, emotional blockade with separation of premature parts of the self, non-epilepsy and, in contrast, complex-focal epilepsy. The article describes the history of the female patient and discusses the factors, why the correct diagnosis was misunderstood so easily for other disturbances.
\end{abstract}

Keywords: Misdiagnosis, Epilepsy, Speech Disorder, Face-Paralysis, Partial Paralysis, Dissociative Disturbance, Cataplexia, Narcolepsy, Speechlessness, Mutism

\section{Case of Patient Mrs. E.}

Mrs. E. was born in the end of the 1960ies as the oldest daughter of a physician. 19-year-old, as a schoolgirl, she suffered a heavy traffic accident. Riding her cycle she was overlooked by a car-driver. The opposing party stated that she has ridden her bike at 6:15 o'clock in a dark morning without lamp, so that the driver recognized her too late. When the first ambulance arrived, she was somnolent. In the emergency hospital the X-rays showed a fracture on the right side of her skull with radiation into the cranial base, and another fracture in the front of her face. The staff of the intensive care unit described her as "introvert with speechlessness", which receded, however, quickly. Two days after the accident the patient was transferred on a peripheral neurological station; here a disturbance of the oculomotoric system was detected.

Months later, thanks to her good precensorships, with big strains and considerable problems, the young woman passed the last class of high school. However, since the accident she suffered from phase-wise appearing attention deficits. She began a study, but failed the exams due to these problems. She changed to another study, but had the same difficulties and was not able to finish this education, too. Additionally, she suffered continuously from headaches. In 1994 she took part in a counseling psychotherapy for one year. Because there was no change of her health status, she went into a clinic for psychosomatic disturbances for several months. In October 1995 she began an education in the field of ergo-therapy. The first two semesters ran well, but in the third half-year she got the same difficulties again. Still she passed the intermediate examination, but developed considerable problems when she had a training-period in an old people's home. In 1996 she began psychotherapy with a psychiatrist, but still there was no improvement. Therefore, in 1997, she visited another psychotherapist. In her next educational training period in a home for mental disabled people she again had so many difficulties that she discontinued her education and became jobless. Beginning in August 1999 she took part in a working support program and beginning in spring 2001 she made packaging in a factory. Nevertheless, on the basis of a phase-wise appearing "weakness" this job was also discontinued.

In 2002 Mrs. E. was examined by a consultant of the insurance company, which had to pay for the disturbances due to the accident. Here she reported for the first time in detail about her phases of speechlessness ("Schweigeanfälle"): "In 
addition I have these attacks... starts with the fact that the vocal lips cramp, and if it becomes bad, I've convulsions from my head down to the feet... In the beginning I'm absolutely unable to express myself, I can write, but I had to write with the left hand during such attacks, although I'm right-handed normally. In addition, in this state my eyes do not react anymore." She claimed to have clear consciousness during these attacks and to remember exactly what happened. "Sometimes I have a pause for months, and sometimes it happened twice in a psychotherapeutic meeting. "In particular when in the psychotherapeutic sessions mental excitement occurred, she suddenly was unable to express herself and she was unable to write with her right hand, however, she was always in a state of clear consciousness.

Most of the neurological investigations of the health insurance physician were without findings; in the EEG (electro encephalography) remarkable disturbances of the left and right frontal lobe with prolongation into the temporal lobe were found. The findings showed monomorphic, rhythmic wave forms. But typical epileptic potentials (i.e. sharp-slow-wave-combinations or spike-waves) were not seen. In spite of these negative results, the insurance-company physician still uttered the suspicion of complex focal epileptic attacks and demanded a clarification in a special hospital.

In autumn 2002, Mrs. E. went into a clinic for epilepsy. An MRT proved "large post-traumatic changes in the right temporal lobe", nevertheless, the EEG was without conspicuities. With photo stimulation, hyperventilation and various other charges no epileptic attacks were released and no seizure-typical EEG-waves were found. However, the phases of speechlessness were also observed several times in this hospital. The final report said:" The patient got several times the attacks of speechlessness. Then she was quiet, looked absent, had tears on her face, showed no reaction, however, could write something, but not immediately. A video recording of these states was shown to the patient. She believed to have the tears due to a pressure in her head, which has to go out. In addition she said to have during the attack the feeling that movements were much larger than in reality. She noted on the video also a big stiffness, which corresponds to her subjective feelings ("expressionless, stony"). (...) She wished in such states that people stayed with her, and did not leave her, otherwise she got panic. (...) Sometimes these disturbances appeared every week. In psychotherapeutic sessions she recognized these states several times. Alone at home, she had no need to speak and she believed that she possibly would not note these states of speechlessness. These states also appeared in an office and on a wedding-party. (...) She was not able to tell releasing factors properly. She had the impression that these states were released by charges, however, she was not able to say what was incriminating in a wedding party. (...) Problematical for the patient were the tiredness and exhaustion, both prevented normal activities."

In the end, the conclusion of the epilepsy clinic was that the observed states were not considered as epileptic, but rather more as psychological problems. The disturbance of the patient was classified as dissociative within the scope of a postal-traumatic syndrome. In the opinion of the experts, the patient suffered from an "emotional blockade with splitting of immature parts of the self".

To tell a long story short, the number of different diagnoses which were made for Mrs. E. is impressive. In 1994 a clinic came to the judgment "experiences of insufficiency with problems of separation"; in 1988 a private clinic for psychogenetic disturbances spoke of a "depressive syndrome", the disturbance was classified as exclusive mental generated, without any connections to the brain injury. An occupational-medicine physician diagnosed her in 1998 as a "schizotypic personality disorder with distinctive behavioral conspicuities". In 2001 wrote a psychotherapist: "psychoneurotic symptoms with serious mood variations and motor blockades". In 2001 a neurologist expressed the supposition of a "narcissistic disturbance". Another neurologist meant more carefully: "the described states / attacks are not unequivocal to assign". A special hospital for epilepsy came to the diagnoses: "1. post-traumatic stress disorder, 2. brain-organic psycho-syndrome after brain trauma, 3. no epilepsy".

Once the possibility of an epilepsy was denied unambiguously, the insurance-company physician came to the conclusion that the symptoms of the patient must be caused, hence, purely mental and not as a result of the accident. The responsible insurance company joined this diagnosis joyful and refused to pay any further claims of Mrs. E.

In summer 2003, on account of this diagnosis, the patient came to a psychosomatic clinic and received again a 6-week stationary psychotherapy. In August 2004 she was accommodated in a workshop for disabled persons; here the attacks appeared nearly every day. Typical triggers were restlessness, loud noises and "swarm" of too many people. Hence, in December 2004 she visited another neurologist. This physician diagnosed complex focal seizures and described the anti-epileptic medication Carbamazepin. Taking this medication, the attacks decreased considerably.

As astonishingly as this cornucopia of different diagnoses, were the results of the psychological examinations, found in different institutions. These reached from massive mental restrictions up to high-level talented. An investigation made in 1998 by an employment agency came to the result that Mrs. E. was not able to concentrate for a minimum of three hours and therefore she was not able to work in an occupation on the free job market. In contrast, data of a working support program, carried out in 1999, proved a high-level talent, the power of logical thinking was in the area of an IQ of more than 130. In contrast to this result, an intensive investigation in the Psychological Institute of a University Hospital showed absolutely no high-level talent, but a rather average IQ. Still, at the same time, massive concentration deficits were ascertained. Later a neuropsychologist confirmed these deficits, but only in lighter form. On the other hand, even the psychologists from the University attested massive deficits of the concentration ability.

On account of these inconsistent data the patient was send to the first-author of this article. The 30 year old woman 
reported here spontaneously that she sometimes had "cramps" in such a manner that she was unable to bring out any sentence. Moreover, she said, she sometimes had the feeling, the right leg sinks into the ground, on other days she had the feeling of floating. Test-psychologically no special conspicuities appeared at first. In the very difficult and lengthy "Learning and Memory Test" (LGT-3 of Bäumler, 1974), she produced good results. As well good results (between 6 and 9 Stanine values) were achieved in a difficult general office-working test (ABAT-R [31]). On the base of these test results the suspicion of a concentration weakness was not confirmed.

Absolutely unexpected the rather easy concentration test "d2" [9], then was broken off, because the patient was suddenly complete cognitive blocked and was not able to continue this test. Her efficiency seemed to depend extremely strong on her momentary constitution, what explained the discrepant results of the previous tests.

On account of the suspicion of a psychic disturbance which could have caused this blockade, a personality test (Freiburger Personality Inventory, FPI-R [18]) was performed. The results gave no explanations for her state; Mrs. E. was neither depressive nor mental extremely unstable.

Because the patient lived alone and had no partner, it was spoken about her psychosocial situation. On this occasion, it came to an astonishing change of her behavior. Mrs. E. became suddenly absolutely stiff and reacted no more. The situation was something uncanny, she seemed as if she wants to say something, but was absolutely unable to bring it out. The author asked her, whether she was not able to speak? Then, after some minutes, with infinite effort, she took with her left hand a pencil and wrote: "YES" on a piece of paper. Then the author asked her, if this condition goes away by itself or if he could do anything for her? As a result she laboriously wrote the text seen in Fig. 1. After about $10 \mathrm{~min}$. the movement ability returned bit by bit, however, it lasted about $15-20$ minutes, until the paralysis disappeared completely.

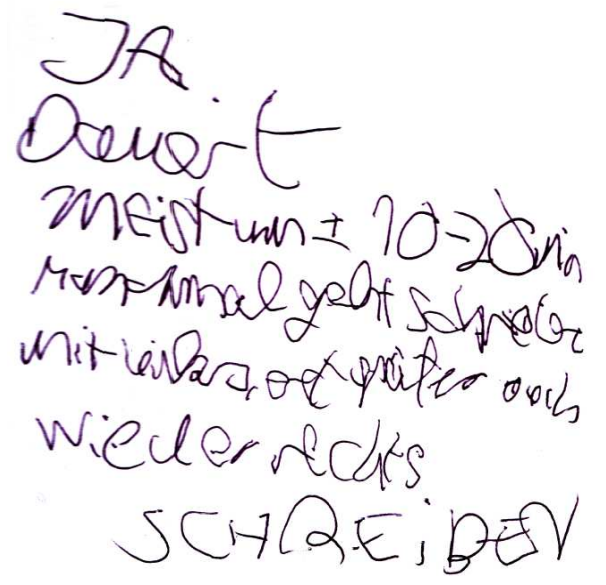

Figure 1. Handwritten note of the patient; she could laboriously write during the attack with the left hand: "YES, needs often about $\pm 10-20$ min sometimes writing goes with left, later again right WRITING."

At a later point of time Mrs. E. gave a document to the author, which contained a very detailed description of her symptoms: "In this text I want to describe more exactly one of my attacks of speechlessness. As far as I can remember, I have had the first attack in a psychosomatic clinic in summer 1994. They appear in very irregular time intervals, sometimes every week - sometimes several times in a week, sometimes I don't have a single one in months. Part of the experts classified these attacks as psychic. In the end of 1999 I had an attack in a "job- takeoff", here it was explained as a result of an excessive demand. On account of akinesia-like symptoms a disturbance of the Dopamine transmitter system was considered. (...) In December 2001, during an EEG investigation, an attack occurred, which clearly stood out in the EEG curves, but was not explained in detail. I noticed later there must have been an attack, because I felt so "mushy" in my brain. This day, when I wanted to buy something on the market, I was only capable to have conversation with sign-language, gesture and facial play. This non-talking-state is the only sure sign: Sentences can be formulated probably, but not pronounced. It was during the job-takeoff that the possibility of written notifications was discovered - depending on the strength of the akinesia, sooner or later, I'm capable to write - generally first with the wrong left hand."

What is the true disorder of this patient?

\section{Discussion}

Already in 1771 the philosopher Mose Mendelsohn described this odd state with his own experiences. In his attacks he had complete consciousness, and was able to follow every thought with order and clearness, but he was incapable of all arbitrary movements, he was unable to move a limb, to give a sound or to open his eyes; and every effort to move was absolutely futile and increased only the adverse sensations which accompanied the state.

In 1877 the symptoms were described by Karl Friedrich Otto Westphal [56]. He reported a sudden loss of the muscular strength during a feeling of big joy. In 1880 Gélineau described two patients with sleeping attacks and phases of odd short paralyses, which he separated clearly from epileptic attacks. From the Greek words "narco" (sleep) and "lepsis" (attack) composed Gélineau the word "Narcolepsia" [19]. Löwenfeld (1902) called the muscle weakness, which is released from emotions and stands in narrow connection with the Narcolepsia, as "Cataplexia" [32]. Still, at first Dornblüth (1894) classified these states in his textbook of psychiatry as hysterical, but later, in 1927, he wrote: "Cataplectic inhibition: Cataplexia, greek kataplêssô = knocking down, fright stiffness; bend of the legs in states of Narcolepsia." [15, 16]

From Daniel (1934) came the first comprehensive treatise about Narcolepsia. He defined this, in most cases chronically running illness, with four main symptoms: Cataplexia, sleeping paralyses, hypnagogíc hallucinations and day drowsiness [13]. In 1975 the disturbed night sleep was fixed as the fifth characteristic feature. For the first time, in 1935 Prinzmetal and Bloomberg [47] used amphetamines as therapy. In the end of the 1950s Methylphenidat (e.g. Ritalin) was used against Narcolepsia and antidepressants (e.g. Imipramin) 
against the states of Cataplexia. Bird (1960) proved that in narcoleptic patients the first REM sleep phase occurs much earlier and these patients fall asleep earlier than healthy subjects [55]. This result was proved with the Multiple-Sleep-Latency-Tests (MSLT): here, the patient is asked to lie down at 5 time points of a day for 20 minutes. In this test, patients with Narcolepsia fall asleep in less than eight minutes.

During sleep, even in the healthy person, a sleeping paralysis occurs, i.e. a loss of the tonus of the muscles. Otherwise, we would make all movements which we are dreaming. Simply explained, in Cataplexia this loss of tonus appears at an absolutely wrong point of time in the middle of a day. Sleep is not a passive state of the brain; it is actively generated by the change of levels of several neuronal transmitters. An essential role for the regulation of the sleep-awake state has, among others, Gamma-AminoButter-Acid, Acetylcholine, Norepinephrine, and Serotonine. Narcolepsia is a disturbance of the sleeping behavior, invincible for the affected person sleeping attacks emerge. This sleeping compulsion last between few minutes up to several hours and can appear several times a day. Sometimes hallucinations occur, for example the hypnagogic sleep-paralyses hallucination; here the patient sleeps, but has the illusion of clear consciousness, and is absolutely unable to move any limb [1, 2, 6, 24]. In Narcolepsia the day drowsiness is the most frequent sign. In particular monotonous activities lead easily to sleeping attacks. As a result of the tiredness the patients often show automatic behavior; they have no difficulties with routine works, but massive problems appear when confronted with new or changed duties. Another after-effect of the tiredness, particularly in long-standing Narcolepsia, is a deficit of concentration. A genetic disposition was described [37], so that also inheritance can play a role. Nevertheless, Narcolepsia can also appear as a result of brain injuries, hormonal illnesses, multiple sclerosis or dementia. Especially lesions of the diencephale brain area are suspicious [14].

Cataplexia, a typical accompanying symptom of Narcolepsia, is the term for the brief loss of the muscle tone. Cataplectic attacks often appear after strong emotions. Triggers are, e.g. fright, laughing, joy, surprise, but also sneezing, cough, orgasm etc. Strangely enough, negative feelings like grief or sorrow hardly lead to catapletic attacks [36]. In about $20 \%$ of the affected persons the paralyses emerges only unilateral. In some patients the whole skeletal musculature is concerned (generalized type), in others only single muscle groups are involved (focal type). In Mrs. E. a brief paralysis of the tongue with loss of the speech occurs, accompanied by an inability to move a hand or a leg (knee weakness) for a period between a few seconds up to several minutes. In a "status cataplecticus" several hours of motionless can appear. In heavy cases the person cannot use the legs and falls down. If only few muscle groups are concerned, the cataplectic attack is often hardly recognized by others and, under circumstances, not even by the affected person him- or herself $[34,35]$. Only $5 \%$ of the patients have more than four of such attacks per day. The patient described above, lived alone, was not employed and therefore the speechlessness struck her hardly, because she was able to think without any difficulties.

Nowadays, the global diagnosis "Narcolepsia" has been divided into three categories:

- Narcolepsia with Cataplexia ("classical Narcolepsia", about $80-90 \%$ of the affected persons),

- Narcolepsia without Cataplexy (mono-symptomatic Narkolepsie),

- Secondary Narcolepsia (symptomatically, e.g. with structural lesions of the hypothalamus or the upper brain trunk as a result of ischemia, tumor, cranial brain trauma).

Typical concomitants are deficits of attention and memory, automatic behavior, accidents due to tiredness or sleeping, depressions, headaches and changes of personality [53]. Depression and personality disorders are known as results of several kinds of brain damages; they can occur reactively, however, they can also be of brain-organic nature [27]. The first manifestation is found predominantly in the second decade of life; only about $20 \%$ of the affected persons develop the disturbance in the first ten years of life [20, 21, 22].

Because an attack often follows an affective situation, Cataplexia is often misdiagnosed as a dissociative syndrome and the patients were send into psychotherapeutic treatment [35]. Misleading is the fact that the paralysis always begins after strong emotions. Therefore it seems reasonable to accept a purely mental causing. In such a dissociative disturbance body-feelings, the control of body movements, recollections of the past and in some cases even the knowledge of one's identity are not represented in the own consciousness. Mental or physical functions were divided from the self, i.e. dissociated. These disturbances are released by traumatic events, e.g. by insoluble conflicts or intolerable relations to others. In the psychoanalytic terminology they are also called "conversion disturbances". Dissociative motor disturbances and sensory disturbances as well as apparently epileptic seizures are typical. Ebel and Algermissen [17] named as general signs of dissociative motor disturbances: Sudden beginning, spontaneous remission; inconsistent symptom presentation; multiple related (but incongruent) neurological symptoms; strong answer to placebo medication; increase of the disturbance due to attention from other people; decrease of the disturbance by distraction; remission under psychotherapy. As one can see, from these points only few apply to the case study described above.

Even more often is the confusion with epilepsy. Zeman reported in 2001 [58] three cases and MacLeod et al. [33] described five children, in which Cataplexia-attacks were mistaken as different forms of epileptic seizures. While Grand-Mal seizures came not into consideration here, Petit-Mal epilepsy can have considerable resemblances with an attack of Cataplexia.

However, according to the directives of the German Society for Neurology (http://www.dgn.org/108.0.html) still several other syndromes must exist: dissociative disturbances; 
epilepsy with atonic attacks without consciousness loss; myoclonia, sporadic sleeping paralysis (in otherwise healthy subjects); pseudo sleeping paralysis with depression (early morning "start difficulties"); neuro-muscle illnesses (e.g. periodical paralysis); syncopes (faint, e.g., cardiogene, vestibulare); orthostatic dysregulation (particularly in young people with dizziness and faint); transitoric ischaemic attacks (TIA).

Moreover, Cataplexia must be separated from the "emotion stupor" ("affect shock"). The latter can appear in an otherwise healthy subject as the result of serious emotions, in particular in the course of an extremely dangerous situation as for example a raid or a heavy accident. As one of the first, Bleuler [8] used this concept in connection with the reaction to strong astonishments in oligophrenic patients. It is more a mental solidification which is expressed than a state of complete immobility. Every now and then descriptions of traffic accidents are found, in which a pedestrian was solidified in a state of mental terror, in which the person was absolutely unable to react any more. In most cases, this emotional stupor occurs only once in a lifetime; in contrast an attack of Cataplexia appears often after very light affects, and recurs in irregular and mostly unpredictable intervals. In regard of cognitive thinking, patients in an attack of Cataplexia have clear consciousness, while in an emotion stupor the person is full of panic.

Often an EEG helps to exclude epilepsy; here especially a long-time EEG makes sense to prove a Narcolepsia. One the other hand, a clear diagnosis of Cataplexia with the help of an electro-encephalography is problematic. In 1962 Roth pointed out, that pathological changes of the EEG-stream often are not observed in a cataplectic attack [49]. In most cases narcoleptic attacks are characterized by the appearance of typical sleeping waves in the EEG. Often these are found in cataplectic attacks with loss of tonus and with sleeping paralysis, too. But on the other hand in an attack of Cataplexia the EEG can show absolutely normal waves $[3,10,23]$.

What is the cause of Cataplexia? Whether Narcolepsia has a genetic basis is still unknown. Honda found in 1986 a correlation between Cataplexia and the histocompatibility leucocyte antigen HLA-DR-2. 98\% of patients suffering from Narcolepsia bear a certain gene (HLA DRB1*1501 or HLA DQB1*0602) and first degree members of genetic-positive Narcolepsia-patients have a 40-fold raised risk [25]. On the other hand, $25-35 \%$ of the normal population has this gene without any pathological sleeping attacks [22, 40, 46]. Hence, one assumes that a part of the affected persons have a genetic disposition, but other additive releasing factors are necessary for an outbreak of this illness. In 1998 Sakurai et al. [50] discovered Orexine (Hyprocretin); at first it was supposed that this peptide deals with the regulation of hunger. With genetic manipulation, Chemelli et al. [12] bred a race of mice, which were unable to produce Orexine. Observations showed that these animals were overwhelmed again and again by brief paralyses, which were comparable with cataplectic attacks in humans. In a race of dogs often suffering from narkolepsia, Mignot [39] found a not-functional Orexine-receptor; though the peptide was produced, it was not effective in the nerve cells. In human patients with Narcolepsia Lin et al. [30] and Siegel [52] proved that a decrease of nerve cells existed in the dorso-lateral hypothalamus, which is responsible for the production of Orexine. In those places where Hypocretin producing nervous fabric should be, in the Narcolepsia patients the scientists found only scar-tissue, while the neighboring Melatonin producing neurons were normal (Melatonin stands in narrow connection with sleep). Today the reduction of Orexine in the brain's liquor is valid as a sensitive proof for Narcolepsia [4, 28, 44, 48]. In addition, Narcolepsia-patients who do not suffer from Cataplexia regularly have a normal level of Hypocretine [45]. The results point out that Cataplexia is caused after a specific damage of Hypocretine producing areas of the brain. Indeed, Buskova et al. [11] ascertained in patients suffering from Narcolepsia and Cataplexia a significant reduction of hypothalamic grey substance.

Is there a treatment? In addition to psychotherapeutic advices (regular day routine, frequent quiescence, no luxuriant meals, avoidance of excitement, no consumption of alcohol) a treatment with medicaments is helpful. Often the sleeping compulsions can be avoided with amphetamines [41, 42, 43]. Antidepressants are recommended against Cataplexia, in particular trizyclic antidepressants (e.g., Imipramin and Clomipramin) which have mood-lightening and impulse-rising effects; also Natriumoxybat (GammaHydroxybutteracid) is admitted. The application of Carbamazepin, which had been prescribed on account of the diagnosis of a focal-complex epilepsy in the above described female patient, is usually not recommended. Zeman [58] described a 41-year-old patient, here this drug showed no positive effects. Also Kobayashi et al. [29] had no luck with this drug. In contrast, Vaughn and D'Cruz [54] had a symptom reduction with Carbamzepine in a 51 year-old patient. Schenck et al. [51] reported positive effects in four of 33 patients with a related syndrome, the sleeping behavioral disorder. Billiard and Carlander [7] recommended the drug for patients suffering from hypersomnia. Carbamazepin, originally an anti epileptic drug, is used as a mood stabilizer in patients suffering from manic-depressive illnesses, if Lithium cannot be taken. Chemically it has certain resemblance with antidepressants. Possibly the effect in the case of the above described young women is based on the fact that the drug leads to a mental stabilization and strong emotions are reduced.

\section{Result for the Practice}

The misdiagnoses for a period of about 20 years in this case study are forgivable. Here, the attacks of speechlessness were the main symptom, while the narcoleptic tiredness was hardly mentioned by Mrs. E. Therefore the right diagnosis was difficulty. While the prevalence of narkolepsia lies in an area of 26 to 50 per 100,000 people [26], Cataplexia is far rarer. Even in most textbooks about sleep disorders Cataplexia is not mentioned [57]. 


\section{Acknowledgement}

The authors thank Mrs. E. for her permission to publish her story here.

\section{References}

[1] Aldrich M. Narcolepsy. Neurology 1992; 42(6): 34 - 43

[2] Aldrich M. Diagnostic aspects of narcolepsy. Neurology 1998; $50(1): 2-7$

[3] Alloway CE, Ogilvie RD, Shapiro CM. EEG spectral analysis of the sleep-onset period in narcoleptics and normal sleepers. Sleep. 1999; 22(2):191-203

[4] Bassetti C, Gugger M, Bischof M, Mathis J, Sturzenegger C, Werth E, Radanov B, Ripley B, Nishino S, Mignot E. The narcoleptic borderland: a multimodal diagnostic approach including cerebrospinal fluid levels of hypocretin-1 (orexin A). Sleep Med. 2003; 4(1): 7-12.

[5] Bäumler G. Lern- und Gedächtnistest LGT-3. Göttingen: Hogrefe, 1974.

[6] Bierbrauer J, Heidenreich T Hilwerling L, von Nessen S, Fey P, Kögel P, Pflug B. Narkolepsie. Nervenarzt 2000; 71:807 - 812.

[7] Billiard M, Carlander B. Troubles de l'éveil: première partie troubles primaires de l'éveil. Rev Neurol (Paris). 1998 Feb;154(2):111-29

[8] Bleuler E.: Lehrbuch der Psychiatrie. Berlin: Springer-Verlag, 1916

[9] Brickenkamp R. Test d2 - Aufmerksamkeits-Belastungs-Test. Göttingen: Hogrefe, 1981

[10] Broughton R, Low R, Valley V, Da Costa B, Liddiard S. Auditory evoked potentials compared to performance measures and EEG in assessing excessive daytime sleepiness in Narcolepsy-Cataplexia. Electroencephalogr Clin Neurophysiol. 1982 Nov;54(5):579-82

[11] Buskova J, Vaneckova M, Sonka K, Seidl Z, Nevsimalova S. Reduced hypothalamic gray matter in Narcolepsy with Cataplexia. Neuro Endocrinol Lett. 2006; 27(6)

[12] Chemelli RM, Willie JT, Sinton CM, Elmquist JK, Scammell T, Lee C, Richardson JA, Williams SC, Xiong Y, Kisanuki Y, Fitch TE, Nakazato M, Hammer RE, Saper CB, Yanagisawa M. Narcolepsy in orexin knockout mice: molecular genetics of sleep regulation. Cell 1999; 98(4): 437 - 451.

[13] Daniels L. Narcolepsy. Medicine 1934; 13: 1 - 122

[14] Dauvilliers Y, Baumann C, Maly F, Billiard M, Bassetti C. CSF hypocretin-1 levels in narcolepsy, Kleine-Levin syndrome, other hypersomnias and neurological conditions. J. Neurol. Neurosurg. and Psychiatry 2003; 74, 1667-1673.

[15] Dornblüth O. Kompendium der Psychiatrie. Verlag Veit \& Comp., 1894.

[16] Dornblüth O. Klinisches Wörterbuch. 13. Aufl., 1927

[17] Ebel H, Albermissen C. Psychogene Bewegungsstörungen. Psychoneuro 2005; 31: 388-391

[18] Fahrenberg J, Hampel R, Selg H. Das Freiburger
Persönlichkeitsinventar - FPI-R. Göttingen: Hogrefe, 1983

[19] Gelineau J. De la narcolepsie. Gazette des Hopitaux (Paris) 1880; 53: 626-628.

[20] Guilleminault C, Brooks SN. Excessive daytime sleepiness: A challenge for the practising neurologist, Brain 2001; 124(8): $1482-1491$

[21] Guilleminault, C, Partinen M, Quera-Salva MA, Hayes B, Dement WC, Nino-Murcia G. Determinants of daytime sleepiness in obstructive sleep apnea. Chest 1988; 94: 32-37

[22] Guilleminault C, Pelayo R. Narcolepsy in prepubertal children. Ann. Neurol. 1998; 43: 135-142.

[23] Hadjiyannakis K, Ogilvie RD, Alloway CE, Shapiro C. FFT analysis of EEG during stage 2-to-REM transitions in narcoleptic patients and normal sleepers. Electroencephalogr Clin Neurophysiol. 1997 Nov;103(5):543-53

[24] Hohagen F, Schönbrunn E. Die Narkolepsie und andere Formen der Hypersomnie. In: M. Berger (Hrsg.): Handbuch des normalen und gestörten Schlafs. Springer-Verlag, Berlin-Heidelberg-New York 1992.

[25] Honda Y, Juji T, Matsuki K, Naohara T, Satake M, Inoko H, Someya T, Harada S, Doi Y. HLA-DR2 and Dw2 in narcolepsy and in other disorders of excessive somnolence without Cataplexia. Sleep. 1986; 9(1/2):133-142.

[26] Hublin, C, Partinen M, Kaprio J, Koskenvuo M, Guilleminault C. Epidemiology of narcolepsy. Sleep 1994; 17: 7-12.

[27] Kasten, E., Gothe, J. \& Müller, I. (2003) Psychische Störungen nach Hirnschädigung. Psychomed 15/4, S. 214- 221

[28] Khatami RY, Maret S, Werth E, Rétey J, Schmid D, Maly F, Bassetti C. A monozygotic twin pair concorsant for narcolepsy-Cataplexia without any detectable abnormality in the hypocretin (orexin) pathway. Lancet 2004; 363: 1199-1200.

[29] Kobayashi Y, Miyamoto M, Miyamoto T, Yamazaki K, Hirata K, Kanbayashi T, Shimizu T. [Nacrolepsy manifesting initially as Cataplexia and sleep paralysis: usefulness of CSF hypocretin-1 examination for early diagnosis] Rinsho Shinkeigaku. 2002; 42(3): 233-236.

[30] Lin L, Faraco J, Li R, Kadotani H, Rogers W, Lin X, Qiu X, de Jong PJ, Nishino S, Mignot E.The sleep disorder canine narcolepsy is caused by a mutation in the hypocretin (orexin) receptor 2 gene. Cell 1999; 98: 365-76

[31] Linert GA, Schuler H. Revidierter Allgemeiner Büroarbeitestst - ABAT-R. Göttingen: Hogrefe, 1994.

[32] Löwenfeld I. Über Narkolepsie. Münchner Medizinische Wochenschrift 1902; 49: 1041

[33] Macleod S, Ferrie C, Zuberi SM. Symptoms of narcolepsy in children misinterpreted as epilepsy. Epileptic Disord. 2005 Mar;7(1):13-17

[34] Mayer, G. Narkolepsie. Berlin: Blackwell, 2000.

[35] Mayer G. Neurophysiologie der Cataplexie. Nervenarzt 2005; 76:1464-1469

[36] Meier-Ewert K. Tagesschläfrigkeit. Ursachen, Differentialdiagnose, Therapie. Weinheim: VCH, Edition Medizin,1989. 
[37] Mignot E. Genetic and familial aspects of narcolepsy. Neurology 1998; 50: (1) S16-S22

[38] Mignot E. Human and animal genetics of sleep and sleep disorders. In: Chokroverty S, (Ed.) Sleep disorders medicine. Boston: Butterworth Heinemann, 1999a.

[39] Mignot E., Young T, Lin L, Finn L. Nocturnal sleep and daytime sleepiness in normal subjects with HLA-DQB1*0602. Sleep 1999b; 22: 347-352.

[40] Mignot E, Lin X, Arrigoni J, Macaubas C, Olive F, Hallmayer J, Underhill P, Guilleminault C, Dement WC, Grumet FC. DQB1*0602 and DQA1*0102 (DQ1) are better markers than DR2 for narcolepsy in Caucasian and black Americans. Sleep 1994; 17 (8): 60-67.

[41] Mitler MM. Evaluation of treatment with stimulants in narcolepsy. Sleep 1994; 17: 103-106.

[42] Mitler MM, Hajdukovic R. Relative efficacy of drugs for the treatment of sleepiness in narcolepsy. Sleep 1991; 14: 218-220.

[43] Nishino S, Mignot E. Pharmacological aspects of human and canine narcolepsy. Prog Neurobiol 1997; 52: 2778.

[44] Nishino S, Ripley B, Overeem S, Lammers GJ, Mignot E. Hypocretin (orexin) deficiency in human narcolepsy. Lancet 2000; 355: 39-40

[45] Oka Y, Inoue Y, Kanbayashi T, Kuroda K, Miyamoto M, Miyamoto T, Ikeda A, Shimizu T, Hishikawa Y, Shibasaki H. Narcolepsy without Cataplexia: 2 subtypes based on CSF hypocretin-1/orexin-A findings. Sleep. 2006; 29(11): $1439-1443$

[46] Poirier G., Montplaisir J, Decary F, Momege D, Lebrun A. HLA antigens in narcolepsy and idiopathic central nervous system hypersomnolence. Sleep 9, 153-158.

[47] Prizmetal, M., Bloomberg, W. 1935. The use of benzedrine for the treatment. of narcolepsy. JAMA 1986; 105: 2051-2054

[48] Ripley B, Overeem S, Fujiki N, Nevsimalova S, Uchino M, Yesavage J, Di Monte D, Dohi K, Melberg A, Lammers GJ, Nishida Y, Roelandse FW, Hungs M, Mignot E, Nishino S. CSF hypocretin/orexin levels in narcolepsy and other neurological conditions. Neurology 2001; 57: 2253-2258.

[49] Roth B. Über das Elektrencephalogramm bei der Narkolepsie-Cataplexie. European Archives of Psychiatry and Clinical Neuroscience 1962; 203( 4)

[50] Sakurai, T, Amemiya A, Ishii M, Matsuzaki I, Chemelli RM, Tanaka H, Williams SC, Richardson JA, Kozlowski GP, Wilson S, Arch JRS, Buckingham RE, Haynes AC, Carr SA, Annan RS, McNulty DE, Liu WS, Terrett JA, Elshourbagy NA, Bergsma DJ, Yanagisawa M. Orexins and Orexin Receptors: A Family of Hypothalamic Neuropeptides and G Protein-Coupled Receptors that Regulate Feeding. Behavior Cell 1998; 92: 573-585

[51] Schenck CH, Boyd JL, Mahowald MW. A parasomnia overlap disorder involving sleepwalking, sleep terrors, and REM sleep behavior disorder in 33 polysomnographically confirmed cases. Sleep. 1997 Nov; 20(11):972-81.

[52] Siegel JM, Moore R, Thannickal T, Nienhuis R. A brief history of hypocretin/orexin and narcolepsy. Neuropsychopharmacology. 2001; 25(5): S14-20

[53] Sturzenegger C, Bassetti C. The clinical spectrum of narcolepsy with Cataplexia: A reappraisal. J. Sleep Res. 2004; 13: 1-13.

[54] Vaughn BV, D'Cruz OF. Carbamazepine as a treatment for Cataplexia. Sleep. 1996; 19(2): 101-103

[55] Vogel G. Study in psychophysiology of dreams. III. The dream of narcolepsy. Archives of General Psychiatry 1960; 3: $421-428$

[56] Westphal T. Eigentümliche mit Einschlafen verbundene Anfälle. Archiv für Psychiatrie und Nervenkrankheiten 1877: 7

[57] Wiegand MH, von Spreti F, Förstl H. Schlaf \& Traum Neurobiologie, Psychologie, Therapie. Stuttgart: Schattauer, 2006.

[58] Zeman A., Douglas N, Aylward, R. Clinical review, Lesson of the week, Narcolepsy mistaken for epilepsy, BMJ 2001;322:216-218 